\title{
The TÜbingen Conspiracy
}

Beat Wyss

In March of 1913, a fragmentary manuscript, a folio written on both sides in the handwriting of Georg Friedrich Wilhelm Hegel, was auctioned off in Berlin. Four years later, after a publication by Franz Rosenzweig, it became known as the "Oldest System-Program of German Idealism." ${ }^{1}$ One hears the murmuring of a genius in this little text, which has been attributed to Schelling, Hölderlin, or Hegel, three friends who studied together in Tübingen. This "fetish" of research on idealism ${ }^{2}$ continues to feed the scholarly debate over the fragment's authorship and the obscurities of its origin and content. ${ }^{3}$

Some new ideas about the purpose of the early public art museums may emerge from the study of the document. It is possible to discern a connecting line of thought, a common concept of purpose, between Hölderlin's idea of 'eternal return' and Mies van der Rohe's Neue Nationalgalerie in Berlin, as well as between Hegel's historicism, Schinkel's Altes Museum and James Sterling's Staatsgalerie in Stuttgart.

For each of the three friends, the SystemProgram would seem to be the seed of later works. In fervent language, the thesis demands the merging of art and philosophy, myth and science. The manuscript must have originated in the Winter of 1796-97, perhaps as an "agitation program" to be read alound to a circle of colleagues. ${ }^{4}$

At this time, Hegel and Hölderlin were employed as preceptors in Frankfurt, which allowed them to pick up their discussions where they had left off in Tübingen. There, they had shared a room with Schelling, and together the three had read Fichte and Rousseau and had founded the league of Reason and Liberty, evok- ing the French Revolution in a transcending light. The System-Program begins with the announcement of a "revolt .... through reason itself." 5 After this great revolution, which would have done away with ignorance, superstition, and proselytizers, the new age would stand under the sign of beauty, for within beauty all concepts of reason are united:

I am convinced now that the highest act of reason, the one in which all other ideas are united, is an aesthetic act and that truth and goodness become closely related through beauty alone.

This philosophy of the future, however, culminates in aesthetics not only in con- 
BEAT WYSS

32 tent, but also in form: Philosophizing itself must become aesthetic: thought should present itself in the form of poetry:

Poetry attains a higher dignity, in the end it will be again what it was in the beginning - teacher of the history of humankind; for there is no more philosophy, no more history, the art of poetry alone will survive all other sciences and arts.

The topos of the great poets as creators of myth and as teachers of the people stems from Johann Gottfried Herder. ${ }^{6}$ Homer and Hesiod had given myth to humankind, but this myth was corrupted by science over the course of history. A final Homer was now anticipated, one who would preserve and fulfill the sciences in a new mythology. Through it, philosophy was to become poetry, and poetry philosophy. The ultimate Gesamtkunstwerk would be identical in form and content: a beautiful expression of the idea of beauty that could embrace everything in perfection.

Friedrich Schelling gave his lecture entitled Philosophy of Art in 1802-03 at Jena, and in 1804-05 at Würzburg. ${ }^{7}$ By then, important points of the anonymous manifesto had been expanded upon and developed as a systematic philosophical project. Like the System-Program, Schelling's Philosophy of Art was prophetic, an aesthetics that is not yet aesthetic itself. Voiced in reflexive prose, it dreams of the flight of poetry: Not philosophical but didactic poetry expresses the highest form of conscience. The ultimate poem would voice the universe so that knowledge about the world would once again be the song of Mytho-poesie, poetry that chants myth:
The absolute didactic poem or the speculative epic becomes one with the fulfillment of science; and, just as science once became independent of poetry, so it is her last and most sublime destination to flow back into this ocean. ${ }^{8}$

As in the System-Program, Philosophy of Art construes history as a circle:

The development runs from the poetic age of antiquity through the scientific prose of modernity to the newly-proclaimed age of poetry, whose last Homer we still await. Therefore, we must draw the same conclusions about the epic that we have drawn about mythology, namely, that Homer, who was the first artist of antiquity, will also be the last in modern art, and will fulfill the ultimate purpose of art itself. ${ }^{9}$

The circular model of history, antiquity versus modernity, is rooted in the Renaissance view of history, which culminated in the Baroque period as the querelle des anciens et des modernes. The systematic polarity of art versus philosophy corresponds to the historic polarity between antiquity and modernity. But just as art and philosophy are merely two different sides of the same truth, antiquity and modernity give shape to the formal contrast of the same beauty. Schelling envisions the abolition of opposites. The fusion of art and philosophy in the didactic poem corresponds on a historical plane to the reconciliation of antiquity and modernity in the memory of aesthetic science:

The history of art will point out to us most clearly its direct connections to the determination of the universe and toward that particular absoluteness for which it is predetermined. The essential and inner 


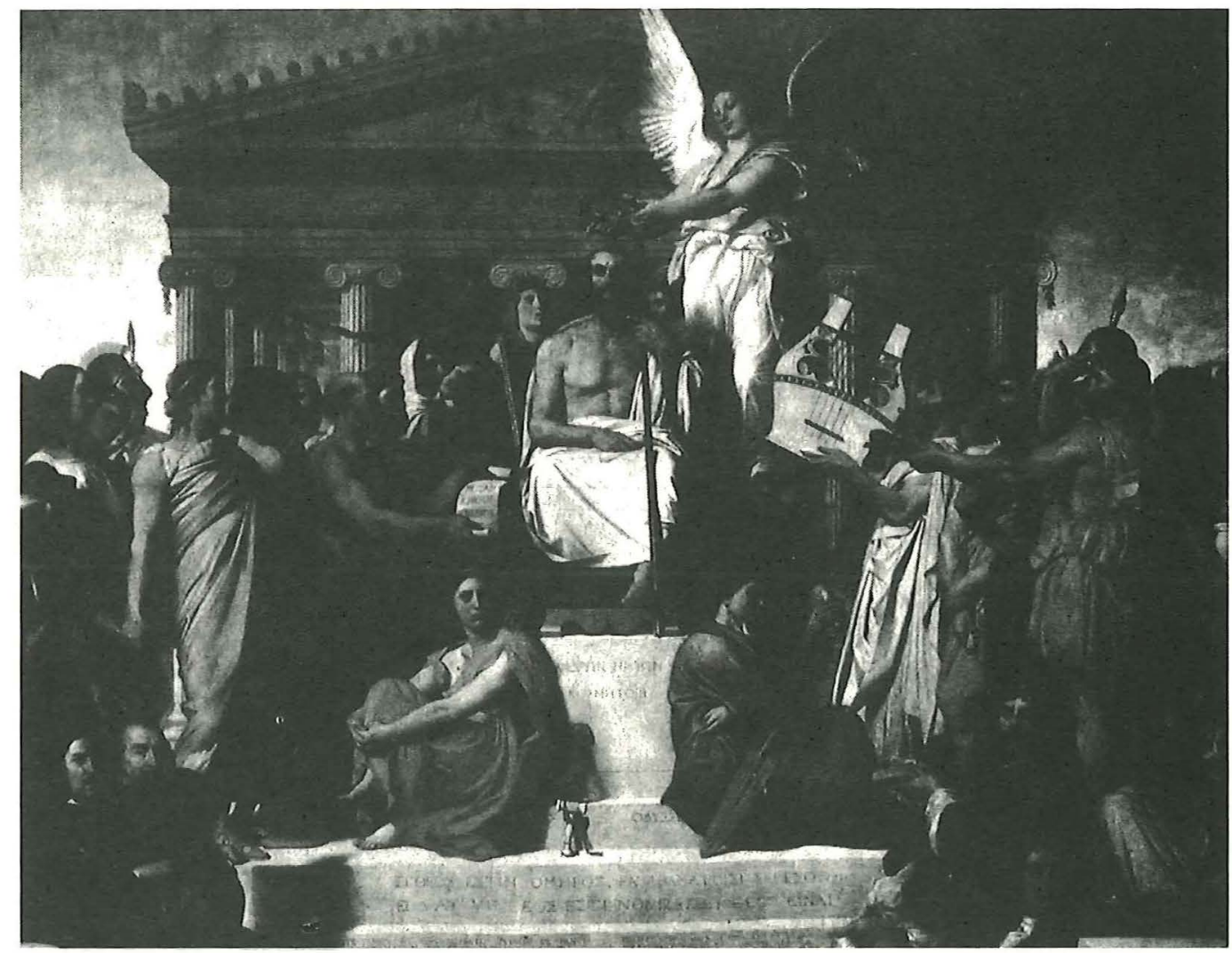

Jean-Dominique Ingres: Apotheosis of Homer, 1828, Paris, Louvre

unity of all artistic creation becomes manifest only in the history of art, showing that all poetry is of one and the same genius, which also shows itself in two different forms as old and new art. ${ }^{10}$

In 1826-27, Ingres painted the Apotheosis of Homer as a ceiling decoration for the exhibition hall of the old Louvre, which Pierre Fontaine had rebuilt for use as a 'museum'. Ingres illustrates The Unity of all Art by grouping artists, musicians, and poets from the history of European civilization around the figure of Homer, who is himself being crowned with a laurel wreath by Nike, the female genius of Victory.
The legitimate genealogy of the civilized old world is spread out before us: at Homer's feet are his spiritual daughters. Ilias and Odysse. Then comes the court of scholars, artists, and poets. Ingres counts them among the sons of Homer - "les grands hommes enfants d'Homer rendant hommage à sa divinité. "11 The simultaneous presence of the Homerids as a community in this tableau demonstrates the identity of beauty as the manifold of those who sing its praises. Homer is the first, the founder of the entire treasury of old world myth. His figure is at once the source and mouthpiece for the noble geneolo- 
BEAT WYSS

34 gy that is the history of civilization; von dorther kommt und zurück deutet der kommende Gott. ${ }^{12}$ In these words of Hölderlin, one can read the two-fold movement of the central perspective in Ingres's painting: The circular movement of the totality Schelling describes is presented here graphically: antiquity and modernity are reconciled through a reciprocity of receiving and giving. Thus Apelles as court painter of Alexander the Great passes his mastery on to Raphael.

As Ingres composed the picture, the garland of occidental spirit paradoxically finds its point de vue in the extinguished eyes of the poet. In the lower right hand corner, the Palmyran rhetorician of late antiquity, Longinus tries to catch the glance of the blind Homer. What he writes about it will in turn become the model for the modern artist Nicolas Boileau, who laid down the rules of French classicism with his L'art poétique in 1674, and whom we see at work in the painting. In his blindness, Homer looks into the future; at the same time, he is commemorated by his descendants, who look back toward his face. On the left of the painting, Poussin teaches us that it is not only the famous, the guests of honor, but we too, who are intended to profit from the example of the observer in this painting: making eye contact, he shows us which way to look.

Ingres himself, the painter of this picture, takes up the role of the last Homer, depicting the first Homer surrounded by his Homerids: The sum of occidental civilization is sacra conversatione of its principal representatives. In this image, intended for the ceiling that hangs above the Egyptian collections of the Louvre, the romantic classicism of Ingres marries the first poet to the first high culture of the old world. Homer serves Mnemosyne, goddess of memory and mother of the muses. Ingres thus establishes the connection between the concept of 'museum' and that of an institution that houses the works of visiual artists. What Homer creates with his verses, the museum presents in its galleries and halls, in those convolutions of the public memory that safeguard the testimonies of material culture. The word 'museum' was not always connected with the process of caring for works of art. In antiquity, painting never achieved the value that it would achieve in modern times. The muses were goddesses of science, poetry, and music. Plato began his philosophical teachings at the Hekedemeia, the academy at the gates of Athens, by offering a prayer to the muses. The designation of this word 'museum' to describe a place where art objects would be exhibited is directly connected with a revolutionary cultural act that effected a brutal inversion of the public conscience: On January 21, 1793, the King of France was executed. The case file names the condemned Louis Capet. This was indeed a pointed humiliation: Louis XVI of the Capets, a public figurehead, was degraded to the status of private individual with the family name of a civilian, while his property was made public. The king's nationalized art treasures were exhibited in the orphaned Louvre under the title 'musée'.

The idea of the museum was forged in the white heat of the "terror". As an ideal project, it had existed for even longer: in 1783 , ten years before the opening of the Louvre, Etienne-Louis Boullée designed his "Project for a Musäon", a "monument to public gratitude." The building was 


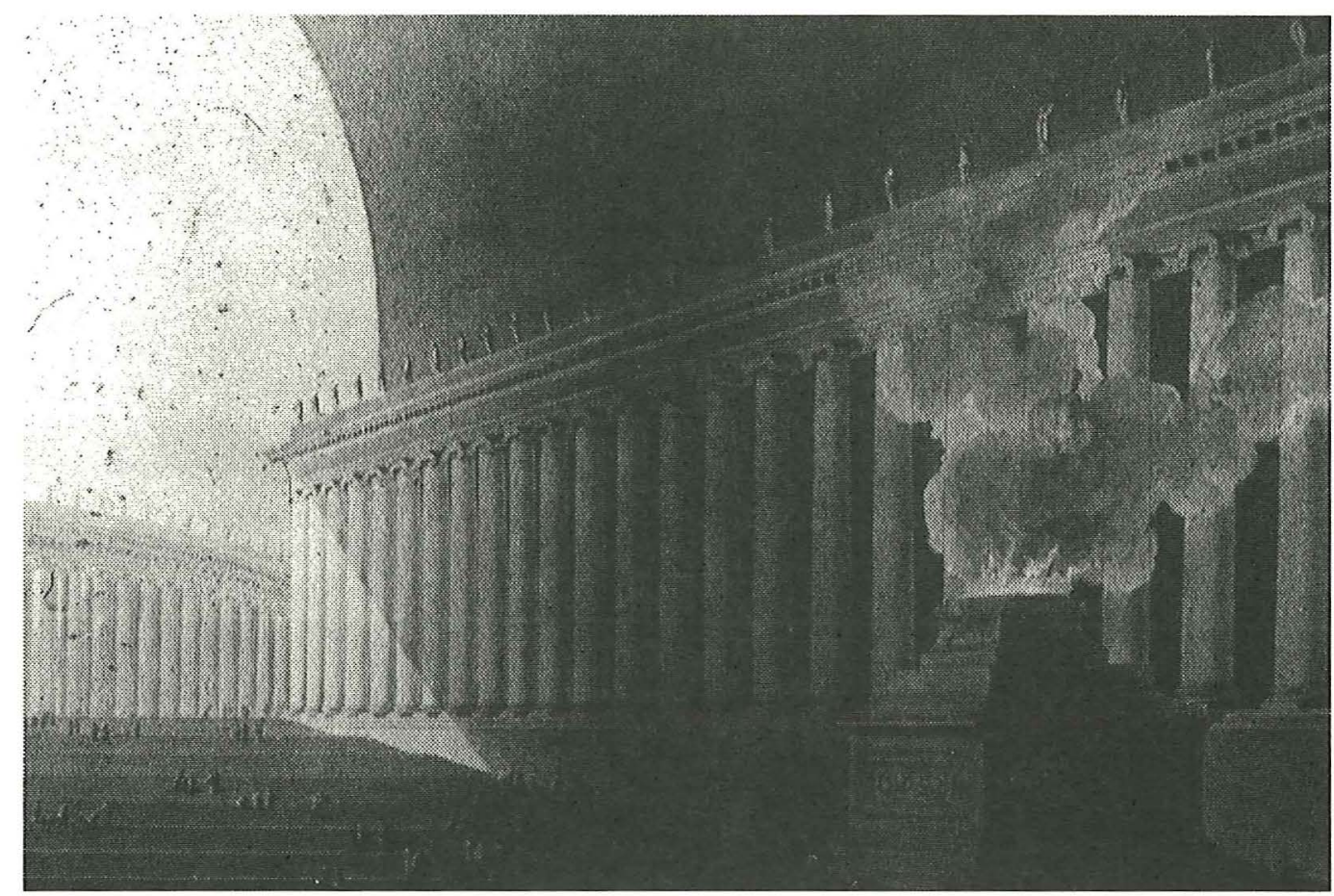

Etienne-Louis Boullee: Stairway of the Musaeon, perspective, 1783, Paris, Bibliotthèque Nationale

planned as a place of worship, a place for paying homage to a new political order:

Here, in front of you, lie all riches with which the people will sustain and beautify the lives of their benefactors. $^{13}$

The museum is not only a place for the collection of curiosities of nature and artifice of man; it is also the place where the people and their leaders come together to express their political identity. This intention constitutes the difference between the modern museum and the princely collections we have known since the Renaissance. The System-Program, 13 years later, adresses related ideas in its demand for an identity of aesthetics and politics, for a new mythology of reason in beauty:

At last the enlightened and unenlightened must shake hands, mythology must become philosophi$\mathrm{cal}$, the people must become reasonable, and philosophy must become mythological in order to make philosophers sensual. The eternal unity will reign in our midst.

Die Aesthetisierung des Politischen Lebens, which Walter Benjamin ${ }^{14}$ noticed in fascism, has its roots in la Terreur, the dark side of enlightenment.

Boullée's museum consists of an immense emptiness, a void. This place is not first and foremost a house for art objects from the past, but rather a place to experience the sublime presence of a new public. For 
36 Boullée, the idea underlying his museum architecture is to mettre la nature en oeuvre, to put nature into the work of art. Whatever is found disassembled in nature must be assembled in the building. In this way, art makes visible what nature only vaguely dreams of. The architecture of the Musäon effects completion of the universe through artifice.

\section{HÖLDERLIN AS DIDACTIC POET}

The second of the possible authors for the System-Program is Friedrich Hölderlin, to whom Germanists have attributed the text. ${ }^{15}$ His Hyperion was written in the same year $1797 .{ }^{16}$ Hölderlin's view of history moves, like that of Schelling, within the dualism of ancient and modern. Unlike his fellows, the philosophers, the poet does not seek an Aufhebung, a reconciliation of this duality in thought alone: Hölderlin hopes for their redemption in life itself. His claim for happiness is the most radical of the three friends from Tübingen. The happiness of Hellas had its source in the unity of myth and life. Hölderlin's poem Bread and Wine describes how the pneuma of the gods was introduced into the life of mortals: ${ }^{17}$

Father Aether! one cried, and tongue after tongue took it up then,

Thousands, no man could bear life so intense on his own;

Shared, such wealth gives delight and later, when bartered with strangers,

Turns to rapture; the word gathers new strength when asleep:

Father! Clear light! and long resounding it travels, the ancient

Sign handed downn, and far, striking, creating, rings out. So do the Heavenly enter, shaking the deepest foundations, Only so from the gloom down to mankind comes their Day.
Imagine these verses resounding from the steps of Boullée's museum, and combining it with a term of Heidegger, Hölderlin's poetosophic pupil, call it: die Lichtung, the illuminated clearing where the gods assemble.

The configuration of galleries linked to a central rotunda became the standard plan for museum architecture in the nineteenth century. Gallery and cupola prescribe the "movement foreward" and the "pausing", the two most basic behaviors of the museum visitor. The antiquities gallery at the Villa Albani, where Winckelmann was director, is just one example of a museum typology that has its origins in 15 th century. ${ }^{18}$ The space invites you to move back through the tunnel of time into the equipoise of the 'pantheon' of preserved history. The coming of the gods gave rise to the cultural achievements of people: the presence of mythos in daily life brought about art:

Now in earnest he means to honour the gods who have blessed him,

Now in truth and in deed all must re-echo their praise.

Nothing must see the light but what to those high ones is pleasing,

Idle and bungled work never for Aether was fit.

So, to be worthy and stand unashamed in the heavenly presence,

Nations rise up and soon, gloriously ordered, compete One with the other in building beautiful temples and cities, Noble and firm they tower high above river and sea.... ${ }^{19}$

What did Hölderlin see when he wrote thus? How much did he know about the art and architecture of antiquity? He knew very little. Hölderlin was able to study the expensively illustrated work by Comte de 
Choisseul-Gouffier, a travel account of Greece and Asia Minor entitled Voyage pittoresque en Grèce, ${ }^{20}$ in the library of the banking family Gontard of Frankfurt/Main, for whom he worked as a tutor. Here he found his Diotima. While leafing through Choisseul-Gouffier's official reports, written in the spirit of enlightened rationalism, the enthusiastic Hölderlin must already have been struck by the painful transitoriness of beauty. For in these pages, the retired French ambassador to Constantinople speaks about the reality of the Ottoman empire, while in fact the ideal of Hellenism existed only as a pile of rubble.

Thus, the poem Bread and Wine abruptly cuts short exuberance: after a dash, there is the shadow of doubt.

Only, where are they? Where thrive those famed ones, the festival's garlands?

Athens is withered, and Thebes; now do no weapons ring out In Olympia, nor now those chariots, all golden, in games there,

And no longer are wreaths hung on Corinthian ships?

Why are they silent too, the theatres, ancient and hallowed?

Why not now does the dance celebrate, consecrate joy?

Why no more does a god imprint on the brow of a mortal

Struck, as by lightning, the mark, brand him, as once be would do?

Else he would come himself, assuming a shape that was buman,

And, consoling the guests, crowned and concluded the feast. ${ }^{21}$

The one who completed the feast of antiquity was Jesus. Since the reference to the Nazarene is introduced with the word 'else', the Christian act of salvation is effectively cancelled, and becomes one mythological language among other possibilities. The illustrators of Voyage pittores- que have mercilessly demonstrated that the Greek ideal was merely present as past. Not the chariots of the Homeric Achaen, but instead merchants with their camel caravans moved through the landscape.

Where thrive those famed ones, the festival's garlands?

Meanwhile, a Turk smokes his pipe in front of the ruins of the mausoleum near Melassa.

But, my friend, we have come too late. Though the gods are living,

Over our heads they live, up in a different world.

Endlessly there they act and, such is their kind wish to spare us,

Little they seem to care whether we live or do not.

For not always a frail, a delicate vessel can hold them,

Only at times can our kind bear the full impact of gods.

Ever after our life is dream about them. But frenzy,

Wandering, helps, like sleep; Night and distress make us strong

Till in that cradle of steel heroes enough have been fostered,

Hearts in strength can match heavenly strength as before.

Thundering then they come. But meanwhile too often I think it's

Better to sleep than to be friendless as we are, alone,

Always waiting, and what to do or to say in the meantime

I don't know, and who wants poets at all in lean years.?2

Hölderlin's poem Bread and Wine was written in 1800-01, one year before Schelling's lecture on the Philosophy of Art announcing the appearance of the last Homer. But for the poet, the edifice of utopian hope for a mythical age has already developed a crack: Hölderlin vascillates between solemn expectation Till in that cradle of steel heroes enough have been fostered, irony such is their kind wish to spare us, and despair and who wants poets at all in 
BEAT WYSS

lean years?

But what the poetry achieves as far as form is concerned, it refuses in content: the return of the gods is cast into doubt. The poem does redeem a principal demand of the System-Program: It is a narrative philosophy about the history of mankind in free verse. Of the three conspirators in the spirit of the SystemProgram, Hölderlin, with his power of speech, would have been the one qualified to write the consummate didactic poem. But the utopian circle of the eternal return of Hellenism had been broken: Bread and Wine only faintly tolls the twilight of the West like a small, cracked vespertine bell. The last Homer had taken his leave.

\section{HEGEL AS ART HISTORIAN}

The awakening of the three confederates from the aesthetico-political dream of their youth opens up three paths: Schelling's path to an esoteric revelatory philosophy, Hölderlin's disappointment over the silence of the gods, and as I will try to show in the following, Hegel's confession of the bourgeois sobriety in enjoying art well tempered. Instead of chanting the eternal return of Hellenism, he would come to see it as his duty to understand the progress of western reason. It is this attitude, quitting the enthusiastic spirit of the System-Program, which would be the foundation for art history and museology. Evidently there eksists an inner connection between the sober bourgeois insight into the historic necessity and the incorruptibly sober view of the museologue, who does not collect art because of its beauty but rather for its authenticity.

Hegel adhered to one precondition that is imperative for the museological conscience, but which his two colleagues lacked, namely, the zeal for hunting and gathering. When he was called to Heidelberg in 1816, he met Sulpiz Boisserée and saw the latter's collection of old German and Dutch art. The connoisseur-like handling of artworks - die Kennerschaft - underlies Hegel's aesthetics. In 1818, he was called to Berlin, and there he was among the frequent visitors to the royal art collections. $\mathrm{He}$ also undertook three extended journeys during the summer and fall to study artworks. In 1822, one of these journeys took Hegel from Cologne - via Brussels, Ghent, Antwerp, and Amsterdam - to Hamburg and then back to Berlin. In 1824, he visited Prague and Vienna; in 1827, Paris.

From the observations he made during his travels, and from what he read about archaeology and art history - which could at that time still be surveyed easily by a single individual - Hegel assembled his 'imaginary museum'. ${ }^{23}$ His first lecture on aesthetics at Heidelberg took place about fifteen years after Schelling's Philosophy of Art and Hölderlin's Bread and Wine, and twenty years after the writing of the System-Program. Worlds lie between these utopian claims and what was to come. What does not change is the all-embracing gesture: the idea that the entire history of humankind can be grasped as a whole. One important difference, however, lies in Hegel's objectifying description of art. Schelling had been satisfied with paraphrasing Winckelmann's pronouncements, which time and again had as their basis variations on the theme of "noble simplicity and sober greatness". Hegel, however, closely examined, even touched the 


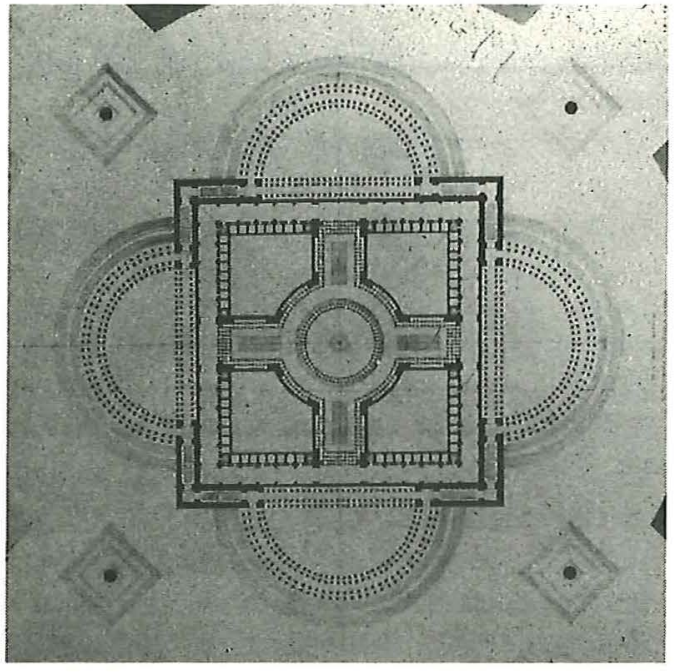

Boulée: Musaeon, Groundplan

objects, in his endeavor to collect concrete knowledge about art. One letter to his wife during the 1822 trip serves as an example:

In Aachen, I first visited the cathedral and sat on Charlemagne's chair: it is made of two marble slabs, each 1 and $1 / 2$ inches thick, which are smooth on their sides as well as at the back; they were, however, covered with gold-foil, of which some pieces still remain and into which stories had been engraved. Three hundred years after his death, Charles was found sitting on this chair, by the Emperor Friedrich, I believe, dressed in the vestments of the emperor, the crown on his head, the sceptre in one hand, and the imperial globe in the other .... I sat down on this chair, on which 32 emperors had been crowned - as the custodian assured me just like anyone else - and the whole satisfaction lies in the fact of having sat upon it. ${ }^{24}$

Hegel reveals himself here as an antiquarian and connoisseur, who, with a touch of irony, keeps his accuracy free of all pedan-

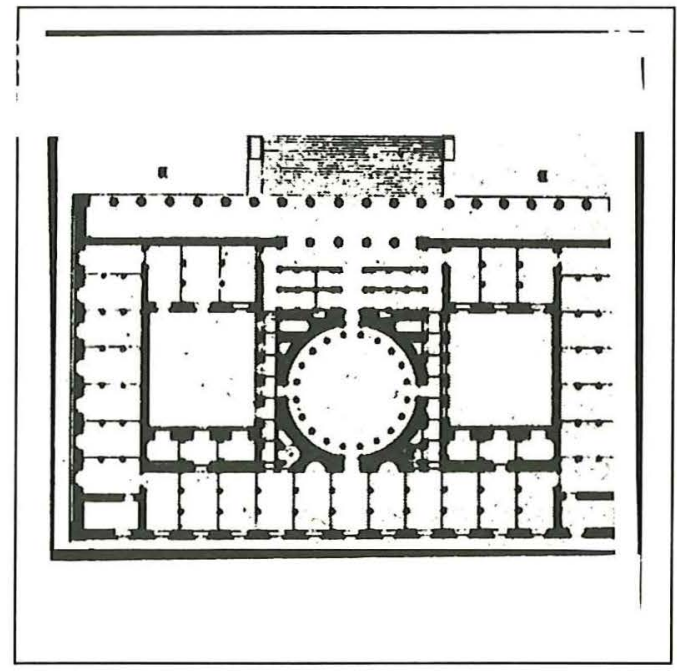

Karl Friedrich Schinkel: Altes Museum Berlin, Floorplan, 1825

try or sourness. Beyond that, he signalled the cultural and political turning away from romanticism in his less-than-respectful treatment of the emperor's throne. A Swabian by birth, but Prussian by conviction, Hegel refused to take the rediscovery of the Carolingian throne as a sign of the return of a German Empire. The eternal return, whether of the Greeks or a Barbarossa, was to him little more than a joke.

Beyond this sober objectivity, another difference between Hegel and his colleagues' views of history becomes evident in his ironic accession to the throne: The dualistic model of history - ancient versus modern - had been overcome. This dualism of culture and spirit, which for Schelling circles within itself like Yin and Yang around the static point of absolute identity prior to all historic time, is eclipsed by historicity in Hegel. He exchanges the return of myth for the principle of historic progress, at the culmination of which 
BEAT WYSS

40 Hegel himself, the philosopher of reason, literally takes the throne.

The bipolar and static circular model of history is replaced by a three-phase dynamic evolutionary model. Hegel divides world history into three great epochs, and nature and spirit develop in three stages that correspond to these three epochs:

$\begin{array}{ll}\text { 1) Symbolic } & \begin{array}{l}\text { Persia } \\ \text { India }\end{array} \\ & \text { Egypt } \\ \text { 2) Classical } & \text { Ancient Greece } \\ \text { 3) Romantic } & \begin{array}{l}\text { Occidental Art from } \\ \text { the Middle Ages to the present }\end{array}\end{array}$

The necessary and reasonable path of humankind leads to perfection in these three stages. Hegel not only developed his historical philosophical project in lectures on aesthetics: it can also be seen in the Altes Museum, designed and built by Karl Friedrich Schinkel on the Museumsinsel at Berlin. The building, planned in 1822 and opened in 1830, is located in the vicinity of the Kupfergraben, where Hegel had his apartment. The Altes Museum can be interpreted as Hegel's philosophy of history expressed in stone. ${ }^{25}$ As a member of the Wissenschaftliche Kunstverein of Berlin, he took part in discussions about the plans for the building of the museum. Gustav Friedrich Waagen, one of Hegel's students from Heidelberg, would become the first director of the museum, and the collections were exhibited according to chronological epochs and topographic regions. In walking through the museum, the visitor could reconstruct the working of the Hegelian Weltgeist, so to speak. According to the original exhibition concept, the museum would unfold the work

of the spirit in a reflexive state of self-awareness.

In only one room the continuity of progress seems to be interrupted: In the rotunda at the building's center, which was designed after the Pantheon, were housed the most beautiful objects in the collection. Do we have a break here in Hegel's philosophical concept of history? Did the idea of progress stumble over the convention of classicism and the eternal return in precisely this place? Not at all. Hellenism had once more unfolded its "luminous empire" of beauty in the center of the building, harmoniously situated at the center of world history, and from which flow the four wings of the museum. In these large suites, the building speaks the prose of inevitable progress. Poetry has withdrawn to the transitory age of the Greeks, which was literally preserved inside the concentric annual rings of time. In this way, Hellenism was at once idealized and neutralized. Hegel's philosophy of history simultaneously explained the uniqueness of the ideal of antiquity and the impossibility of ever attaining this ideal again.

Here, in the pantheon of physical harmony, the visitor could find solace in the "breath and scent of mourning", ${ }^{26}$ which the gods felt about their own perfection. The Prussian protestant surpassed the Greek just in his ugliness, for he had recognized that he must depart from the realm of mere physical beauty for the sake of historic progress. The citizen who had come of age took upon himself the passion of everyday life with the same "heroism of subjugation" 27 with which Christ had once taken up the cross, and, "consoling the guests, crowned and concluded the feast". ${ }^{28}$ 


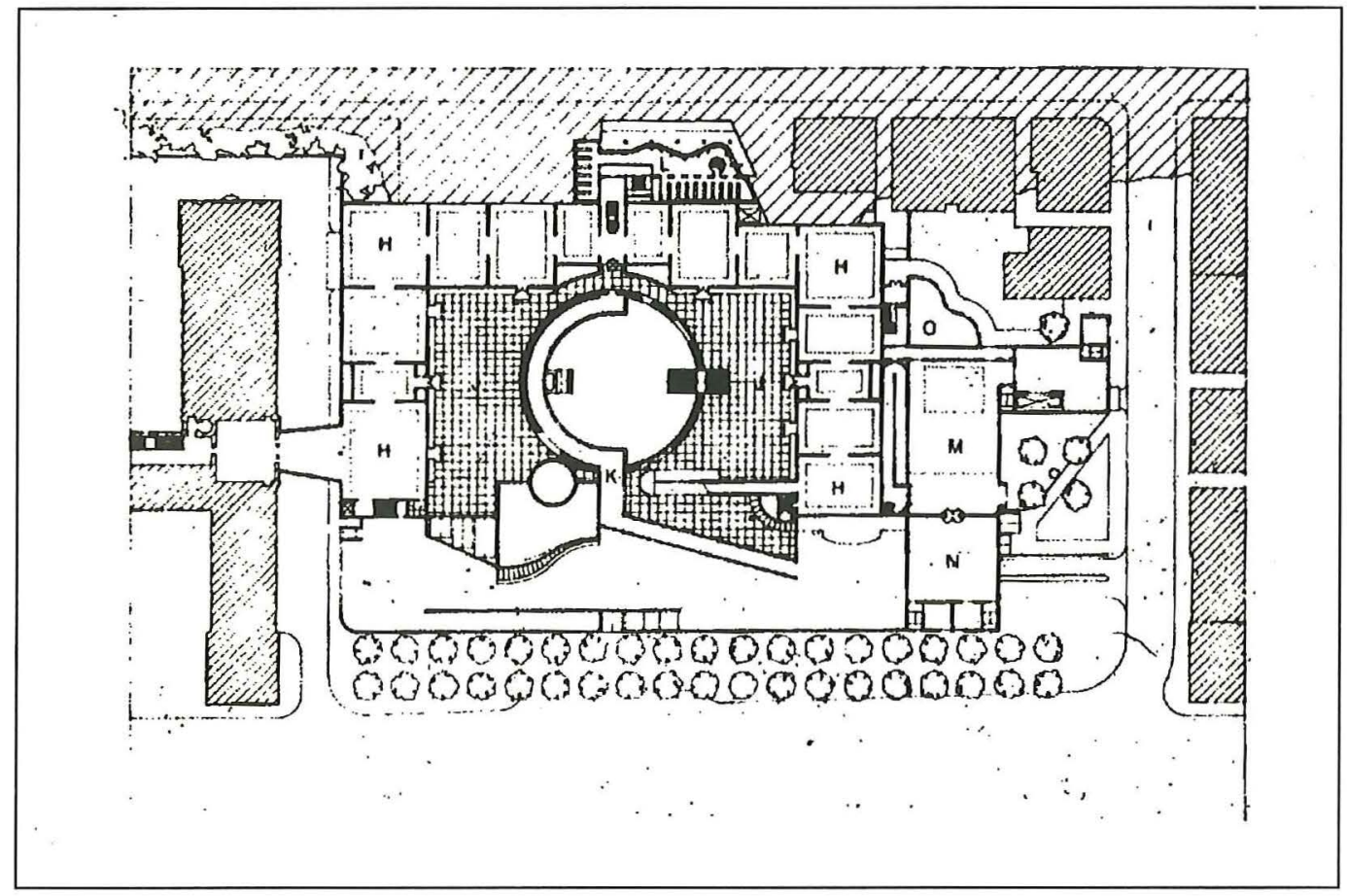

Herein lies the central difference with respect to the classicism of the Enlightenment in which Hölderlin remained rooted. It demanded the unconditional and uncompromising presence of the ideal, whose shape at the same time signalled the renewal of humankind in the spirit of the ancients. Not only the artistic style, but also the democracy of the Athenian polis was worthy of imitation. The classicism of a Hegel and a Schinkel would be constituted very differently only a generation later: Impregnated by the experience of the political restoration, the imitative zeal dissolved into mere formal historicism. Hegel's aesthetics supplied the justification for building in Berlin in the manner of the Athenians, as well as for the preserva- tion of the Prussian monarchy: one was explained by the echo of the ideal, the other through the progression of the reeasonable and real (das Ver-nünftig - Wirkliche).

Housing art in the museum only became possible with the idea of history as progress. Hegel's and Schinkel's concept for the museum ushers in the historicism of the second half of the nineteenth century. Art now served as proof of past progress, along which the viewer could walk in the galleries of the museum. The idea of art offering the promise of redemption, the return of the state of beauty into its eternal presence was only accessible in the form of a mere aesthetic experience, to enjoy within carefully separated, vaulted niches. Schinkel himself explained his 


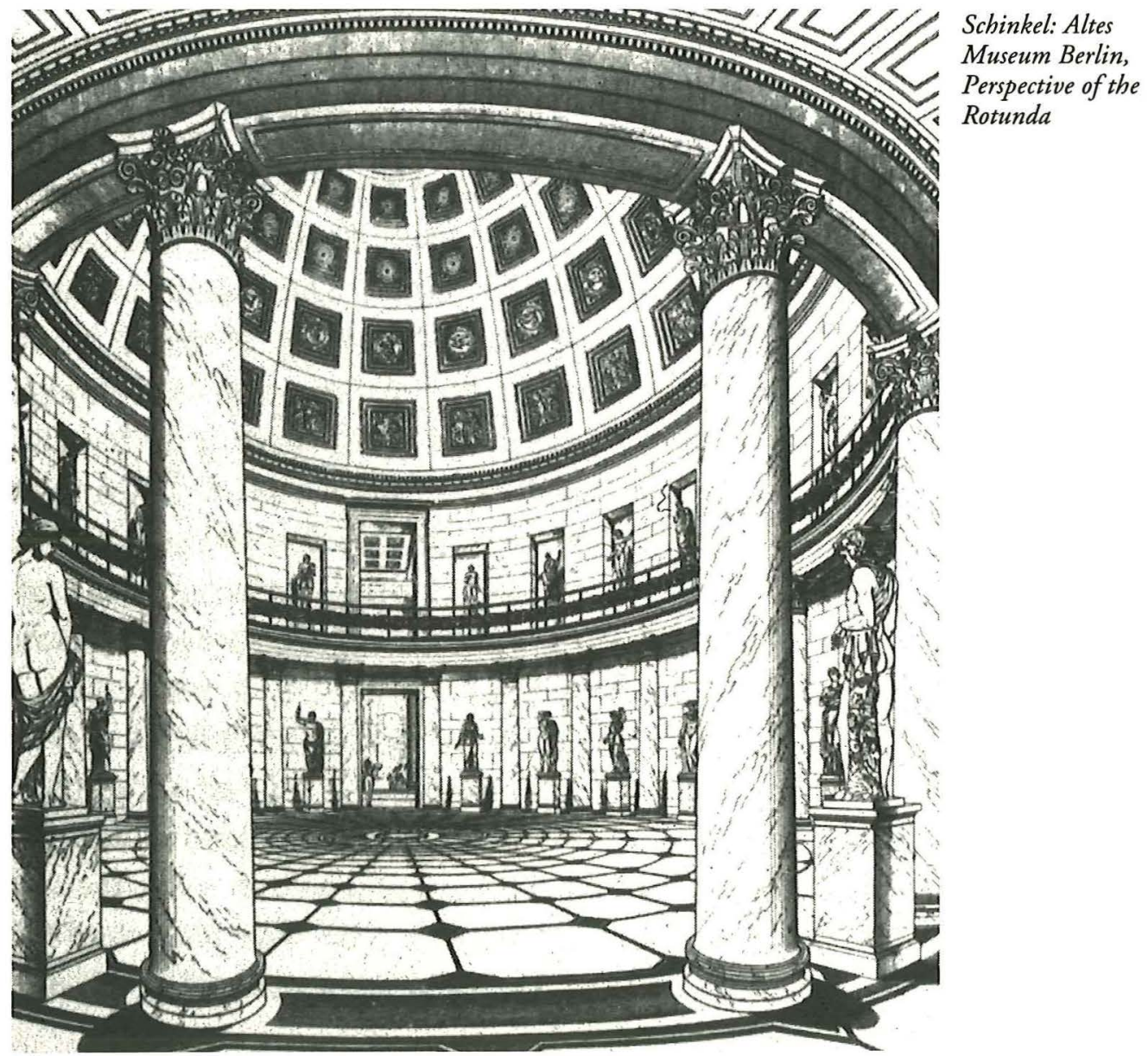

rotunda in the Altes Museum:

The visitor enters this place first after leaving the outer hall. Therefore, the view of a beautiful and noble room must prepare the visitor and instill in him a mood conducive to enjoyment and the recognition of that which the building actually houses. ${ }^{29}$

\section{MODERNIST POST-SCRIPT}

This bourgeois compromise of internalized artistic enjoyment, divided and fram- ed by the pressure of progress, would be dismissed by classical modernity: Mies van der Rohe's National Gallery in Berlin takes up once again Hölderlin's idea of eternal return. Mies did away with the threshold between everyday life and art in his building, and thus retracts Hegel's notion of the empire of beauty as a vanished one. Only a wall of glass separates art from life. If Schinkel's rotunda is separated from the outside world by an outer porch and suites of galleries, the interior 
of Mies' National Gallery is already visible from the street.

The building of the National Gallery is inscribed as an artificial architectural square, united with the outside world by osmosis through the glass skin of its walls, while Schinkel's floorplan pulls the sphere of art back into its snail shell of historicity, where, everything is relative to progress in time.

The architecture of the eternal return is, however, not favorable in terms of the management of a museum. Experts deplore the difficulty of installing art in a gallery that is too light near the glass walls and too dark at the center of the room.

In order to rescue the museum built according to the historicist concept, there must be an acknowledgment that the sheer hunger for presence in a Hölderlin, a Mies, does not stimulate building places of commemoration or of historical tolerance. As long as the return of the Greek gods was part of the museological program, huge portions of non-European, archaic, and medieval epochs, as well as entire epochs of modern times, could not be considered. The regard of a Hegel for the "ugly" old German or Dutch painters only became possible with the historic relativation of the classical canon. Not until Hegel did philosophical aesthetics experience an objectivization in a two-fold way: first, the thing itself, the art object became the object of theory; second, the claim of art history, as such, was objectified. The reawakening of the poetic age was no longer the question, but rather simply to understand the art forms within the framework of their historical and social conditions. The purpose of universal history was not the song of eternal return, but rather the protocol of progress in the sense of what is reasonable and real. From the story of Zarathustra down to the Prussian state, and not the other way around! It was not until Hegel's objectivization of aesthetics that art history became possible. A thought process that no longer had to demand an ideal, but that was able to proceed from the acceptance of everyday ordinariness, comprised the mental foundations of the museum, which would have the social task of enriching this ordinariness by collecting objects and transforming them into national treasures.

Hegel had put aside the youthful pathos of change. His history of philosophy soberly leaves behind the vision of the System-Program:

No Homer, no Sophocles, no Dante, Aristo, or Shakespeare can emerge in our time. What was at one time celebrated and spoken of so freely has been said; it is the way things were looked at and

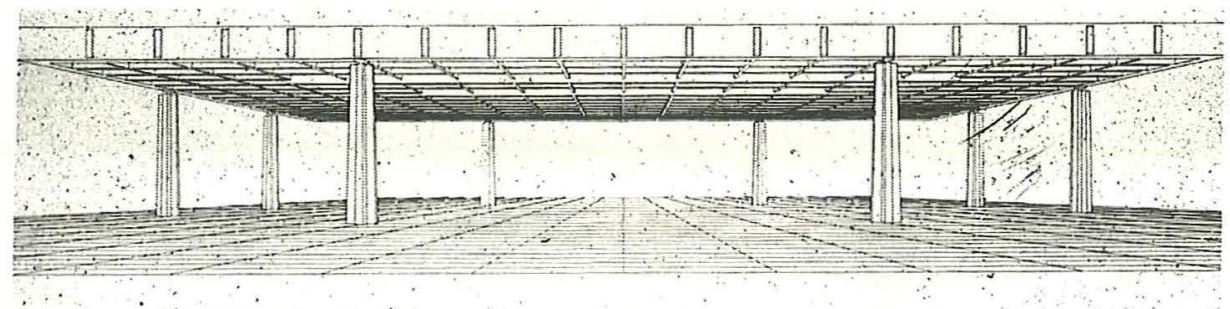




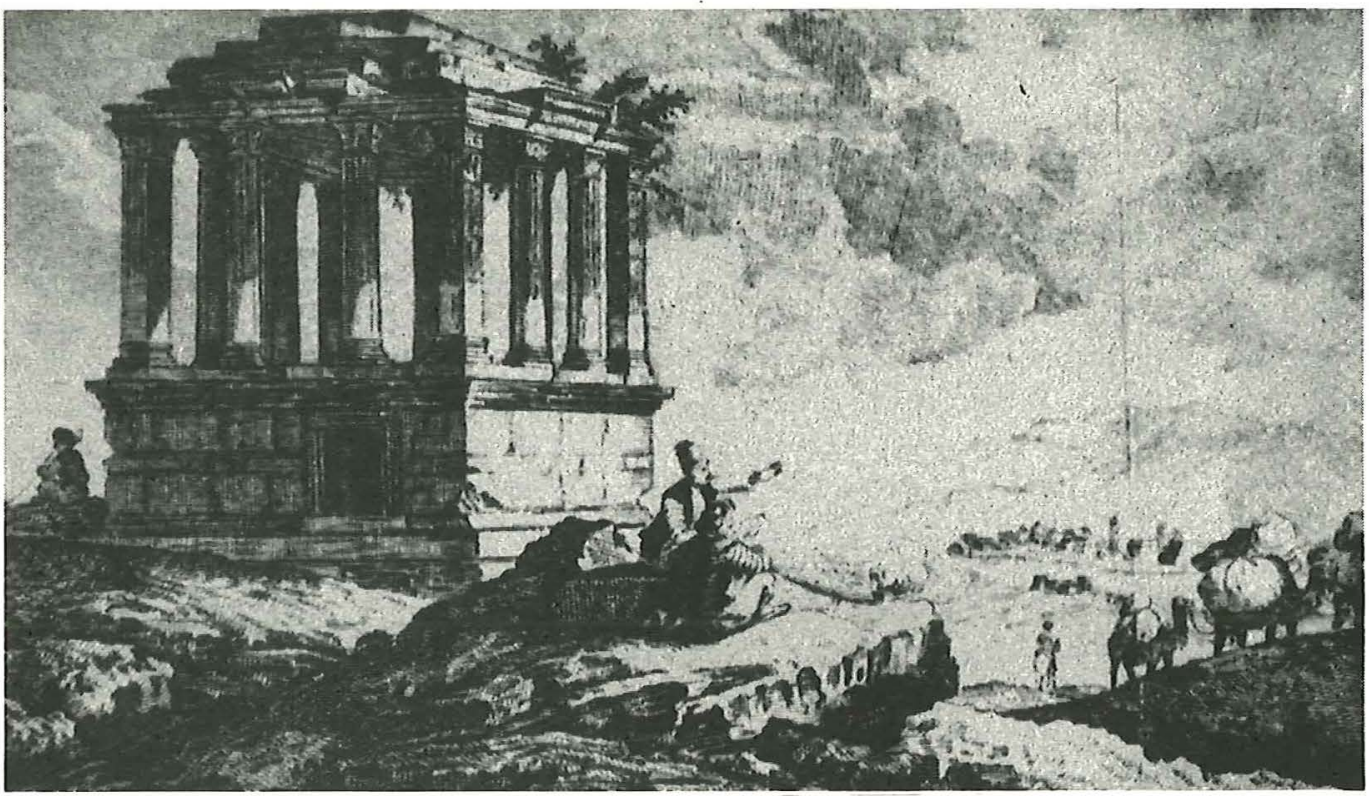

Melassa, Mausoleum. Illustration out of: Voyage pittoresque de la Grèce..., Paris 1782

thought about that is over now. Only the presence is fresh, the rest is pale and becomes paler. ${ }^{30}$

Like Hölderlin, Hegel foregoes his last Homer, not out of resignation, but rather out of pragmatism.

The museum came to replace the universal poem about humankind. Instead of the last Homer, an army of art historians should step forward to harvest the fruits of history and bring them into the barn. For one notion put forward in the SystemProgram has persisted, namely, that we are living in a dying age. The great epochs are gone forever.

Art invites us to reflective contemplation, not in order to bring about art once again, but to recognize art in a scientific way. ${ }^{31}$

Thus, the epoch of artists is replaced by the epoch of art historians; where once we had the last poet, we now have the first museum guides ...

Schelling's Philosophy of Art saw antiquity as the world of historical myth, and the new age as the world of knowledge. Contrary to Schelling, however, Hegel demands no return of mythical poetry. His statement from the preface of the Philosophy of Law, in which he settles the account with the romantic within himself ${ }^{22}$, became famous:

If a philosophy paints grey on grey, then a figure of life has become old, and no one can rejuvenate her with grey on grey, rather only recognize her; the owl of Minerva only begins her flight at twilight..$^{33}$

Hegel's twilight is no Ragnarök, but rather just evening after a day's work is done. The philosopher admits that dealing with art is in itself

the best wages for hard work in the real world and 
for the bitter pain suffered in gaining knowledge. ${ }^{34}$

Hegel's concept of the museum as a covered walkway that takes the viewer through history has in particular been taken up in the postmodern age. James Stirling's State Gallery in Stuttgart contributes to the genius loci by quoting at Hegel's birthplace the floorplan of the Altes Museum at Berlin. An enfilade of four wings with suites of rooms surrounds a rotunda. In the center is the shielded-off circular area where art experience, the eternal return, takes precedence over the principle of historic progress. No one marches rigorously on in the Hegelian sense. Rather, visitors amble at their leisure in the direction of the exit from history.

Art as a promise of eternal return or as document of progress? To experience the objects aesthetically or historically are the two tendencies of museum display that have been engaged in fruitful competition since the age of Enlightenment. Instead of taking hold of one or both of these opposite tendencies, a too successful museological praxis now seems just flattly to divide one by the other.

\section{NOTES}

1. Franz Rosenzweig, Das älteste Systemprogramm des deutschen Idealismus, Ein handschriftlicher Fund, in: Sitzungsberichte der Heidelberger Akademie der Wissenschaften, PhilosophischHistorische Klasse, 1917, 5. Abh.

2. Christoph Jamme and Helmut Schneider, Mythologie der Vernuft, Hegels 'ältestes Systemprogramm' des deutschen Idealismus', Frankfurt a. M. 1984

3. A compilation of the different standpoints, see: Jamme und Schneider (footnote 2); Manfred
Frank and Gerhard Kurz, Materialen zu Schellings philosophischen Anfangen, Frankfurt a. M. 1975

4. Dieter Henrich in: Jamme und Schneider (footnote 2), p. 156

5. "Einen Umsturz .... durch die Vernuft selbst". An edition of the Systemprogramm, see: Jamme and Schneider (footnote 2), p. 11-14

6. Among other texts, see the so called Preisschrift von 1778: Über die Würkung der Dichtkunst auf die Sitten der Völker in alten und neuen Zeiten, in: Johann Gottfried Herder, Sämtliche Werke, ed. by Bernhard Suphan, vol. 8, Berlin 1892, pp. 334-436

7. published in 1859; reprint by Wissenschaftliche Buchgesellschaft, Darmstadt, 1980

8. Philos. der Kunst (footnote 7), p. 311

9. Philos. der Kunst (footnote 7), p. 329

10. Philos. der Kunst (footnote 7), p. 311

11. quoted by: Norman Schlenoff, Ingres et ses sources litteraires, Paris, Presses Universitaires de France, 1956, p. 154

12. "From whence he comes, he points back towards the coming God" (see footnote 17).

13. "Les voilà, ces resources nombreuses avec lesquelles la Nation voudrait conserver et embellir les jours de ses bienfaiteurs". Etienne Louis Boullée: Architekture, essai sur l'art, ed. by JeanMarie Pérouse de Montclos, Paris, Hermann, 1968, p. 71.

14. Das Kunstwerk im Zeitalter seiner technischen Reproduzierbarkeit, Frankfurt a. M. 1963, p. 48

15. Wilhelm Böhm, Hölderlin als Verfasser des 'Ältesten Systemprogramms des deutschen Idealismus', in Deutsche Vierteljahrsschrift fuir Literaturwissenschaft und Geistesgeschichte 4 (1926), p. 339-426; Ludvig Strauss, Hölderlins Anteil an Schellings frühem Systemprogramm, in: Deutsche Vierteljabrsschrift fiur Literaturwissenschaft und Geistesgeschichte 5 (1927), p. 679-734; Friedrich Strack, Nachtrag zum 'Systemprogramm' und zu Hölderlins Philosophie, in: Hölderlin-Jahrbuch 21 (1978- 


\section{1979), p. 67-87}

16. Hyperion oder der Eremit in Griechenland, first volume, Tübingen 1797

17. (German original) Friedrich Hölderlin, Sämtliche Werke, 'Frankfurter Ausgabe', Band 6, Elegien und Epigramme, hg. v. D. E. Sattler und W. Groddeck, Frankfurt a. M. 1976, unemendierter Text V, S. 248-252. A German/English edition, see Friedrich Hölderlin, Poems and Fragments, transl. by Michael Hamburger, Cambridge, pp. 242-253.

18. See Marcin Fabianski, Iconography of the Architecture of Ideal Musaea in the 15th to 18th Centuries, in: Journal of the History of Collections, vol. 2, no. 2, 1990, pp. 95-134.

19. (German original) (see footnote 17).

20. Marie-Gabriel-Augusta-Florent, Comte de Choiseul-Gouffier: Voyage pittoresque de la Grece, 2 vol., Paris 1782, 1809 , p. 145 , Pl. 85

21. (German original) (see footnote 17).

22. (German original) (see footnote 17).

23. A summary of Hegel's concept of art history, see: Beat Wyss, Trauer der Vollendung, Von der Ästhetik des Deutschen Idealismus zur Kulturkritik an der Moderne, München 1985.

24. Johannes Hoffmeister (Hg.), Briefe von und an Hegel, Hamburg 1952-1960, 2nd vol., p. 355.

25. Beat Wyss, Klassizismus und Geschichtsphilosophie im Konflikt, Aloys Hirt und Hegel, in: Hegel-studien, Beiheft 22, p. 115130; Douglas Crimp: The End of Art and the Origin of the Museum, in: Art Journal, College Art Association of Amerika, Winter 1987, Vol. 46, No 4, p. 261-266

26. "Hauch und Duft der Trauer", see Hegel, Werke, Vollständige Ausgabe durch einen Verein von Fremden des Verewigten, Berlin 1832-1845, 10. Band, 2. Abt. p. 77

27. "Heroismus der Underwerfung", see Hegel, Werke, 10. Band, 2. Abt., S. 131 (see footnote 26)

28. "vollendet und schloss tröstend das himmlische
Fest" (see footnote 17)

29. "Diesen Ort betritt man zuerst, wenn man aus der äusseren Halle hineingeht und hier muss der Anblick eines schönen und erhabenen Raumes empfänglich machen und eine Stimmung geben für den Genuss und die Erkenntnis dessen, was das Gebäude überhaupt bewahrt". Quoted by Carl Otwin Rave, Carl Friedrich Schinkel. Lebenswerk, Berlin 1941, vol. 11.1, pp. 32-33. 30. "Kein Homer, Sophokles usf., kein Dante, Ariost oder Shakespeare können in unserer Zeit hervortreten; was so gross besungen, was so frei ausgesprochen ist, ist ausgesprochen; es sind dies Stoffe, Weisen, sie anzuschauen und aufzufassen, die ausgesungen sind. Nur die Gegenwart ist frisch, das andere fahl und fahler." Hegel, Werke, 10. Band 2. Abt., p. 236 (see footnote 26).

31. "Die Kunst lädt uns zur denkenden

Betrachtung ein, und zwar nicht zu dem Zwecke, Kunst wieder hervorzurufen, sondern, was Kunst sei, wissenschaftlich zu erkennen." Hegel, Werke, 10. Band, 1. Abt. p. 16 (see footnote 26).

32. Concerning the political background of the Systemfragment and early Hegel see Otto Pöggeler, Das Menschenwerk des Staates, in: Jamme und Schneider (footnote 2), p. 175-225

33. "Wenn die Philosophie ihr Grau in Grau malt, dann ist eine Gestalt des Lebens alt geworden und mit Grau in Grau lässt sie sich nicht verjüngen, sondern nur erkennen; de Eule der Minerva beginnt erst mit einbrechender Dämmerung ihren Flug." Hegel, Werke, 8. Band, S. 20-21 (see footnote 26).

34. ".... den besten Lohn für die harte Arbeit im Wirklichen und die sauren Mühen der Erkenntnis ausmacht." Hegel, Werke, 10. Band, 3. Abt. S. 581 (see footnote 26).

Beat Wyss är professor $i$ konsthistoria vid Institut fir Kunstgeschichte, Rubr-Universität, Bochum Adr. Hansaring 8, D-50670 Cologne 